\title{
Keanekaragaman Moluska di Pantai Pasir Putih Lampung Selatan
}

\author{
Gres Maretta $^{1)}$, Nurhaida Widiani ${ }^{2)}$, Nella Indry Septiana ${ }^{3)}$ \\ ${ }^{1}$ Program Studi Biologi, Jurusan Sains, Institut Teknologi Sumatera, Way Hui, Lampung Indonesia \\ ${ }^{2,3}$ Program Studi Pendidikan Biologi, Fakultas Tarbiyah dan Keguruan, UIN Raden Intan Lampung, Indonesia \\ *) Alamat korespondensi: gres.maretta@bi.itera.ac.id
}

\begin{abstract}
ABSTRAK
Pantai Pasir Putih merupakan daerah dengan substrat pantai yang bervariasi yang banyak menyimpan keanekaragaman jenis Moluska. Keanekaragaman Moluska di perairan Lampung masih sedikit diketahui, oleh karena itu penelitian yang dilakukan di Pantai Pasir Putih, Lampung Selatan bertujuan untuk mengetahui kepadatan dan keanekaragaman Moluska, serta untuk menentukan kualitas perairan. Metode pengambilan sampel yang digunakan adalah transek garis yang dikombinasi dengan metode kuadran. Moluska yang ditemukan sebanyak 48 individu yang berasal dari 9 famili (Cerithiidae, Neritidae, Throchidae, Conidae, Muricidae, Nassaridae, Columbellidae, Buccinidae dan Mactridae). Berdasarkan hasil perhitungan kepadatan Moluska $\left(10,33 \mathrm{Ind} / \mathrm{m}^{2} ; 5 \mathrm{Ind} / \mathrm{m}^{2} ; 0,67 \mathrm{Ind} / \mathrm{m}^{2}\right.$.) Indeks Shannon-Wiener Moluska di Pantai Pasir Putih masuk dalam kategori rendah (nilai $\mathrm{H}^{\prime}: 0$ - 0,152). Hasil analisis faktor lingkungan menunjukkan bahwa perairan Pantai Pasir Putih belum tercemar dan masih cukup baik untuk kehidupan moluska.
\end{abstract}

Kata kunci: Bioindikator, indeks Shannon-Wiener, transek garis

\section{Molluscs Diversity in Pasir Putih Beach South Lampung}

\author{
Gres Maretta $^{1)}$, Nurhaida Widiani ${ }^{2)}$, Nella Indry Septiana ${ }^{3)}$ \\ ${ }^{1}$ Biology Study Program, Department of Science, Institut Teknologi Sumatera, Way Hui, Lampung Indonesia \\ ${ }^{2,3}$ Biology Study Program, Faculty of Tarbiyah and Keguruan, UIN Raden Intan Lampung, Indonesia \\ ${ }^{*)}$ Email: gres.maretta@bi.itera.ac.id
}

\begin{abstract}
Pantai Pasir Putih is an area with a variety of coastal substrates that store much diversity of Molluses species. The diversity of Molluses in the waters of Lampung is still little known, therefore research conducted at Pasir Putih Beach, South Lampung aims to determine the density and diversity of Molluses, as well as to determine water quality. The sampling method used is line transect combined with the square method. Molluses were found in $\mathbf{4 8}$ individuals from nine families (Cerithiidae, Neritidae, Throchidae, Conidae, Muricidae, Nassaridae, Columbariidae, Columbellidae, Buccinidae, and Mactridae). Based on the calculation of Molluses density $\left(10.33 \mathrm{Ind} / \mathrm{m}^{2} ; 5 \mathrm{Ind} / \mathrm{m}^{2} ; 0.67 \mathrm{Ind} / \mathrm{m}^{2}\right.$.) The Shannon-Wiener Molluscs index on the Pasir Putih Beach was included in the low category $(\mathrm{H}$ value: 0 - 0.152$)$. The results of the analysis of environmental factors show that the waters of the Pasir Putih Beach have not been polluted and are still good enough for Molluscs life.
\end{abstract}

Keywords: bioindicator, line-transect method, Shannon-Wiener index

\section{PENDAHULUAN}

Indonesia adalah negara dengan gugus pulau terbesar di dunia yang memiliki laut sangat luas. Pulau yang dimiliki mencapai 17.508 buah, serta panjang garis pantai $81.000 \mathrm{~km}$. Indonesia menyimpan sumber daya alam yang cukup besar baik di darat maupun laut. Laut Indonesia merupakan salah satu yang menyimpan keanekaragaman hayati tertinggi di dunia. Oleh karenanya, kawasan pesisir dan laut Indonesia memegang peranan sangat penting dalam ekosistem [1].

Lampung Selatan merupakan kawasan pesisir bagian Teluk Lampung, yang membentang dari Kalianda sampai Lempasing dan Teluk Semangka di sekitar Kota Agung. Lampung Selatan memiliki banyak wisata bahari yang sangat terkenal, indah dan menarik, salah satu diantaranya yaitu Pantai Pasir Putih. Pantai Pasir Putih merupakan daerah 
pasang surut yang memiliki area yang luas dengan substrat pantai yang bervariasi. Umumnya wilayah pantai banyak menyimpan keanekaragaman jenis Bivalvia (kerang-kerangan) dan Gastropoda (kerabat keong) anggota Filum Moluska merupakan dua kelompok fauna yang banyak dijumpai di Pantai Pasir Putih.

Moluska mempunyai nilai ekonomi tinggi seperti Trochus, Cypraea dan Murex, karena cangkangnya dapat dimanfaatkan sebagai hiasan yang mahal dan juga dapat dijadikan bahan makanan yang bergizi seperti Cymbiola dan Mytilus viridis [2]. Selain itu, kelompok hewan ini memegang peranan penting dari segi ekologi. Moluska merupakan penyusun ekosistem perairan yang berperan dalam penyediaan makanan untuk berbagai spesies lain dalam rantai makanan. Moluska juga dapat menjadi bioindikator, mengingat adanya perubahan atau gangguan pada lingkungan tentunya akan memengaruhi struktur komunitas Moluska.

Perubahan struktur penyusun komunitas dapat berperan sebagai indikator adanya tekanan atau gangguan di suatu ekosistem [3]. Pantai Pasir Putih telah banyak dikonversi menjadi kawasan pelabuhan perikanan, pertambangan, kawasan pemukiman, industri dan pariwisata. Perubahan tersebut baik secara langsung atau tidak langsung memberikan dampak yang memengaruhi ekosistem baik biota maupun kondisi lingkungan. Salah satu biota yang dapat terpengaruh akibat perubahan lingkungan yaitu Moluska. Keberadaan dan penyebaran Moluska sangat dipengaruhi faktor abiotik dan biotik, seperti sumber makanan, kondisi lingkungan, pemangsa dan kompetisi. Adanya tekanan dan perubahan lingkungan berpengaruh terhadap total famili dan perbedaan komposisi dari organisme.

Kurangnya data informasi keanekaragaman Moluska dan kondisi perairan di Pantai Pasir Putih, mendorong untuk dilakukannya penelitian ini. Oleh karena itu, penelitian ini bertujuan untuk mengetahui kepadatan dan keanekaragaman Moluska, serta untuk menentukan kualitas perairan di Pantai Pasir Putih Kabupaten Lampung Selatan.

\section{METODE PENELITIAN}

Waktu dan Tempat. Penelitian ini dilaksanakan pada bulan Agustus 2017 di Pantai Pasir Putih Desa Rangai Tritunggal Kecamatan Katibung Kabupaten Lampung Selatan. Pengukuran parameter fisika dan kimia air dilakukan di lokasi penelitian dan Laboratorium Politeknik Negeri Lampung. Identifikasi Moluska dilakukan di Laboratorium Pendidikan Biologi UIN Raden Intan Lampung.

Penentuan lokasi penelitian. Lokasi penelitian ditentukan berdasarkan teknik purposive sampling. Lokasi ini dipilih atas pertimbangan kondisi lingkungan, perbedaan pemanfaatan pantai dan jenis substrat yang mewakili wilayah kajian tersebut. Lokasi untuk pengambilan sampel dibagi menjadi tiga stasiun.

Teknik pengumpulan data. Teknik sampling dilakukan menggunakan metode transek garis yang dikombinasikan dengan metode kuadran. Satu transek garis ditempatkan pada setiap stasiun, yang ditarik secara tegak lurus dari pasang surut terendah garis pantai, kemudian di dalam setiap stasiun dibagi tiga titik pencuplikan. Pada setiap titik pencuplikan diletakkan kerangka kuadran berukuran $1 \times 1 \mathrm{~m}^{2}$ dengan jarak antar kuadran adalah lima meter (Gambar 1). Total pencuplikan semua stasiun adalah sembilan titik pencuplikan.

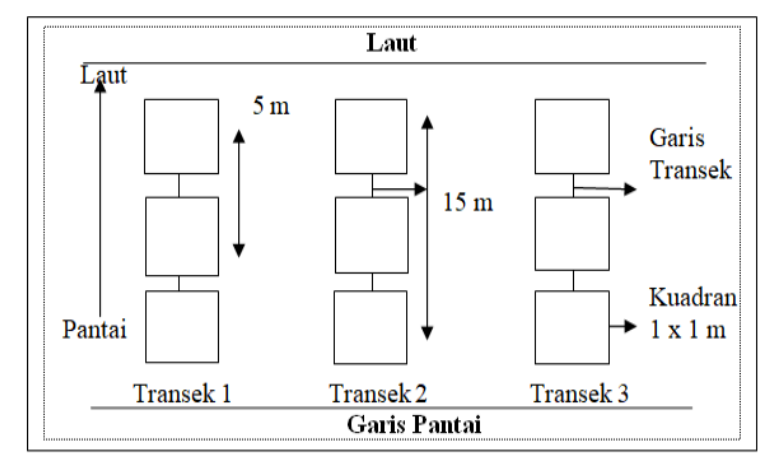

Gambar 1. Desain sampling penelitian

Pengambilan Moluska dilakukan saat surut terendah dengan menggunakan dua teknik, yaitu mengambil secara langsung untuk Moluska epifauna dan mengambil substrat sampai kedalaman $15 \mathrm{~cm}$ untuk jenis infauna. Moluska yang diperoleh termasuk yang ditemukan hanya cangkangnya saja dikumpulkan dan dibersihkan. Setelah itu, sampel yang diperoleh difiksasi dengan menggunakan formalin $4 \%$ lalu diberi label. Pengukuran faktor lingkungan dilakukan dengan mengukur parameter fisika-kimia air, meliputi suhu, kedalaman, $\mathrm{pH}, \mathrm{DO}, \mathrm{BOD}$ dan COD.

Identifikasi Moluska. Identifikasi dilakukan sampai pada tingkat famili dengan mengacu pada buku FAO The Living Marine Resources of the Western Central Pasific Volume 1 [4] dan buku Siput dan Kerang Indonesia (Indonesia Shells) [5].

Analisis data. Kepadatan individu dihitung dengan menggunakan rumus [6]: 
Keterangan:

$$
D=\frac{\mathrm{Ni}}{\mathrm{A}}
$$

$\mathrm{D}=$ Kepadatan Moluska $\left(\mathrm{Ind} / \mathrm{m}^{2}\right)$

$\mathrm{Ni}=$ jumlah individu spesies Moluska

A $=$ Luas area yang terukur dengan kuadran $\left(\mathrm{m}^{2}\right)$

Keanekaragaman suatu biota air dapat ditentukan dengan menggunakan teori Shannon-Wiener ( $\left.\mathrm{H}^{\prime}\right)$ dengan rumus Shannon-Wiener, yaitu [7]:

Keterangan:

$$
\mathrm{H}^{\prime}=-\sum_{i=1}^{S} P i \ln P i
$$

$\mathrm{H}^{\prime}=$ Indeks Keanekaragaman

$\mathrm{Pi}=\mathrm{ni} / \mathrm{N}$

ni $=$ jumlah individu spesies ke- $\mathrm{i}$

$\mathrm{N}=$ jumlah individu total

$\mathrm{S}=$ jumlah jenis

Kriteria indeks keanekaragaman menurut Shannon-Wiener didefinisikan sebagai berikut [8]:

Nilai $\mathrm{H}^{\prime}<1 \quad$ : keanekaragaman jenis rendah

Nilai $1<\mathrm{H}^{\prime}<3 \quad$ : keanekaragaman jenis sedang

Nilai H' $>3$ : keanekaragaman jenis tinggi

\section{HASIL DAN PEMBAHASAN}

Identifikasi Moluska. Hasil identifikasi mengenai keanekaragaman Moluska di Pantai Pasir Putih ditemukan 48 individu yang berasal dari sembilan famili (Tabel 1). Identifikasi Moluska dilakukan berdasarkan morfologi, ukuran, pola warna, corak cangkang serta ciri khusus yang dimiliki.

Tabel 1. Hasil identifikasi Moluska

\begin{tabular}{ccccccc}
\hline \multirow{2}{*}{ No } & \multirow{2}{*}{ Kelas } & \multirow{2}{*}{ Famili } & \multicolumn{3}{c}{ Stasiun } & Jumlah \\
\cline { 3 - 5 } & & I & II & III & Individu \\
\hline 1. & & Cerithiidae & $\sqrt{ }$ & - & - & 22 \\
2. & & Throchidae & $\sqrt{ }$ & - & - & 1 \\
3. & & Conidae & $\sqrt{ }$ & - & - & 1 \\
4. & \multirow{2}{*}{ Gastropoda } & Muricidae & $\sqrt{ }$ & - & - & 5 \\
5. & & Columbellidae & $\sqrt{ }$ & - & - & 1 \\
6. & & Buccinidae & $\sqrt{ }$ & - & - & 1 \\
7. & & Neritidae & - & $\sqrt{ }$ & - & 15 \\
8. & & Nassariidae & - & - & $\sqrt{ }$ & 1 \\
9. & \multirow{2}{*}{ Bivalvia } & Mactridae & - & - & $\sqrt{ }$ & 1 \\
& & Jumlah total & & & & 48 \\
\hline
\end{tabular}

Kepadatan. Stasiun I memiliki kepadatan Moluska tertinggi yaitu $10,33 \mathrm{Ind} / \mathrm{m}^{2}$, sedangkan stasiun II $5 \mathrm{Ind} / \mathrm{m}^{2}$ dan stasiun III memiliki kepadatan terendah yaitu $0,67 \mathrm{Ind} / \mathrm{m}^{2}$ (Gambar 2). Kepadatan Moluska yang tinggi umumnya berhubungan dengan cara hidup dan kemampuan adaptasi yang baik terhadap lingkungan. Stasiun I memiliki kondisi lingkungan yang didominasi pasir berbatu, bongkahan karang, dan terdapat tumbuhan laut. Lingkungan tersebut cukup mendukung dan produktif untuk pertumbuhan Gastropoda. Adanya bongkahan karang dan batu dimanfaatkan untuk melekatkan tubuhnya agar bisa bertahan dari ombak. Gastropoda yang mendiami pasang surut mengalami adaptasi terhadap serangan ombak dengan cara mempertebal cangkangnya [9]. Selain itu, tanaman laut yang tumbuh di sekitar lokasi juga cukup mendukung karena sebagian besar Gastropoda yang ditemukan merupakan herbivora.

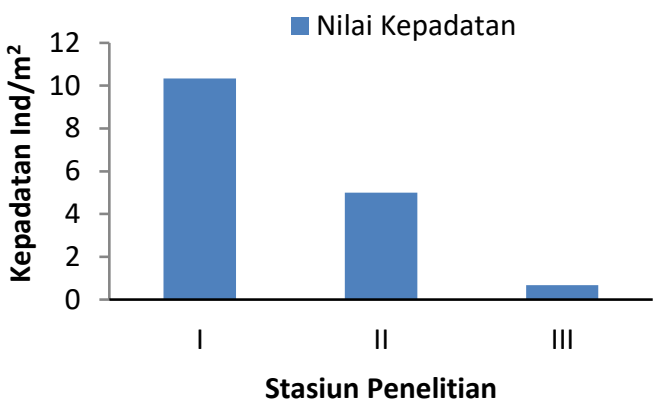

Gambar 2. Kepadatan Moluska

Kepadatan terendah berada pada stasiun III, lingkungan stasiun ini merupakan tipe substrat yang berpasir halus. Tipe substrat ini kurang mendukung untuk kehidupan Gastropoda. Substrat pasir yang halus tidak menyediakan tempat tetap untuk melekatkan tubuhnya, sehingga lokasi ini tidak banyak ditemukan Gastropoda. Namun pada stasiun ini ditemukan Bivalvia. Bivalvia mampu bertahan pada substrat berpasir karena, suka membenamkan diri dengan cara menggali liang di dalam pasir. Tipe substrat berpasir memudahkan Bivalvia dalam memperoleh makanan dan air untuk kelangsungan hidupnya [10]. Pada Stasiun II hanya ditemukan Gastropoda dari famili Neritidae. Ditemukannya Neritidae pada stasiun ini karena kondisi lingkungan bersubstrat pasir dengan sedikit lumpur.

Keanekaragaman (H'). Berdasarkan hasil perhitungan indeks Shannon-Wiener, keanekaragaman Moluska pada stasiun I memiliki nilai keanekaragaman tertinggi yaitu 0,152 . Nilai terendah berada di stasiun II dan III yaitu dengan nilai 0 (Gambar 3). Nilai indeks $\mathrm{H}$ pada semua stasiun tersebut masuk dalam kriteria rendah. Rendahnya keanekaragaman karena tidak ditemukan Moluska dalam jumlah banyak, serta kemampuan individu yang hanya bisa menempati habitat tertentu. Stasiun II memiliki tipe substrat berpasir dengan sedikit lumpur. Pada stasiun II ditemukan Moluska dari kelompok Neritidae dalam jumlah melimpah. 
Tabel 2. Deskripsi Moluska tiap famili

\begin{tabular}{|c|c|c|}
\hline No & Famili & 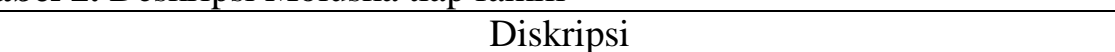 \\
\hline 1 & Famili Cerithiidae & $\begin{array}{l}\text { Cerithiidae memiliki cangkang berukuran panjang } 1-2 \mathrm{~mm} \text { dan lebar } \\
2 \text { - } 4 \text { mm. Warna cangkang coklat dengan bercak hitam, berbentuk } \\
\text { kerucut, memanjang tebal, dan tajam dengan permukaan banyak rib- } \\
\text { rib (tonjolan) pada arah axial. Aperture memanjang dengan canal sifon } \\
\text { pendek dan mencuat. Columella tanpa lipatan spiral yang kuat. Arah } \\
\text { putaran cangkang (torsi) dekstral. Habitat ditemukan berkoloni di atas } \\
\text { substrat pada daerah pasang surut. Cerithiidae banyak ditemukan di } \\
\text { laut dangkal pada daerah tropis. Cerithiidae merupakan hewan } \\
\text { herbivora yaitu memakan detritus dan alga yang membusuk. }\end{array}$ \\
\hline 2 & Famili Throchidae & $\begin{array}{l}\text { Trochidae memiliki cangkang berukuran cukup besar. Cangkang } \\
\text { memiliki lebar lebih pendek dari tingginya. Panjang cangkang } \\
\text { berukuran } 5,4 \mathrm{~mm} \text { dan lebar } 4,2 \mathrm{~mm} \text {. Cangkang memiliki bentuk } \\
\text { kerucut melingkar dengan dasar yang rata. Warna cangkang coklat } \\
\text { semburat putih dengan ukiran secara aksial dan spiral serta memiliki } \\
\text { tonjolan. Sifonnya lebar dan tumpul serta memiliki arah putaran } \\
\text { dextral. Trochidae sebagian besar berada di perairan laut dangkal, } \\
\text { mampu bertahan di substrat berpasir, berbatu dan batu karang. Cara } \\
\text { hidup dengan menyaring detritus dan memakan alga. }\end{array}$ \\
\hline 3 & Famili Conidae & $\begin{array}{l}\text { Cangkang tebal dan berat, bahu cangkang agak menonjol dengan } \\
\text { permukaan sedikit halus. Body whorl sangat besar dengan spire } \\
\text { kerucut ke atas dan tajam. Warna cangkang coklat dengan panjang } 6 \\
\text { mm dan lebar } 3 \mathrm{~mm} \text {. Aperture sangat panjang serta sempit, dengan } \\
\text { canal siphon pendek dan lebar. Memiliki arah putaran dekstral. } \\
\text { Hidupnya ditemukan di substrat batu berpasir pada daerah pasang } \\
\text { surut. Aktif saat malam hari untuk berburu mencari makanan. } \\
\text { Makanannya berupa cacing laut, Moluska lainnya dan ikan kecil. } \\
\text { Hewan ini memiliki panah tajam seperti gigi dan kelenjar beracun } \\
\text { yang mengeluarkan toksin kuat. }\end{array}$ \\
\hline 4 & $\begin{array}{l}\text { Famili Muricidae } \\
\text { a. Genus Ocinebrina }\end{array}$ & $\begin{array}{l}\text { Ocinebrina memiliki cangkang tebal, kuat dengan spire besar } \\
\text { bergerigi dan mencuat. Panjang cangkang berkisar } 2,5-4,5 \mathrm{~mm} \text { dan } \\
\text { lebar } 1-2 \mathrm{~mm} \text {. Permukaan cangkang dengan tonjolan yang kuat } \\
\text { mengarah spiral. Warna cangkang coklat hingga hitam pada bagian } \\
\text { atas. Bagian bawah berwarna coklat terang agak keputihan. Aperture } \\
\text { lonjong dengan anterior canal siphon yang pendek serta arah putaran } \\
\text { dextral. Columellanya halus dan bibir luar bergerigi. }\end{array}$ \\
\hline & b. Genu & $\begin{array}{l}\text { Morula memiliki cangkang berukuran lebih kecil dari Ocinebrina yaitu } \\
\text { panjang } 2,3 \mathrm{~mm} \text { dan lebar } 1 \mathrm{~mm} \text {. Secara keseluruhan morfologi } \\
\text { cangkang hampir sama dengan Ocinebrina. Namun, yang jelas tampak } \\
\text { berbeda adalah tonjolan pada permukaan cangkang. Rib-rib pada } \\
\text { cangkang kedua tampak bulat besar dan berwarna putih. Keduanya } \\
\text { ditemukan di daerah pasang surut pada substrat berbatu berpasir. }\end{array}$ \\
\hline & $\sqrt{1 \mathrm{~mm}}$ & \\
\hline 5 & Famili Columbellidae & Cangkang umumnya berukuran kecil dengan panjang $2,1 \mathrm{~mm}$ dan \\
\hline
\end{tabular}




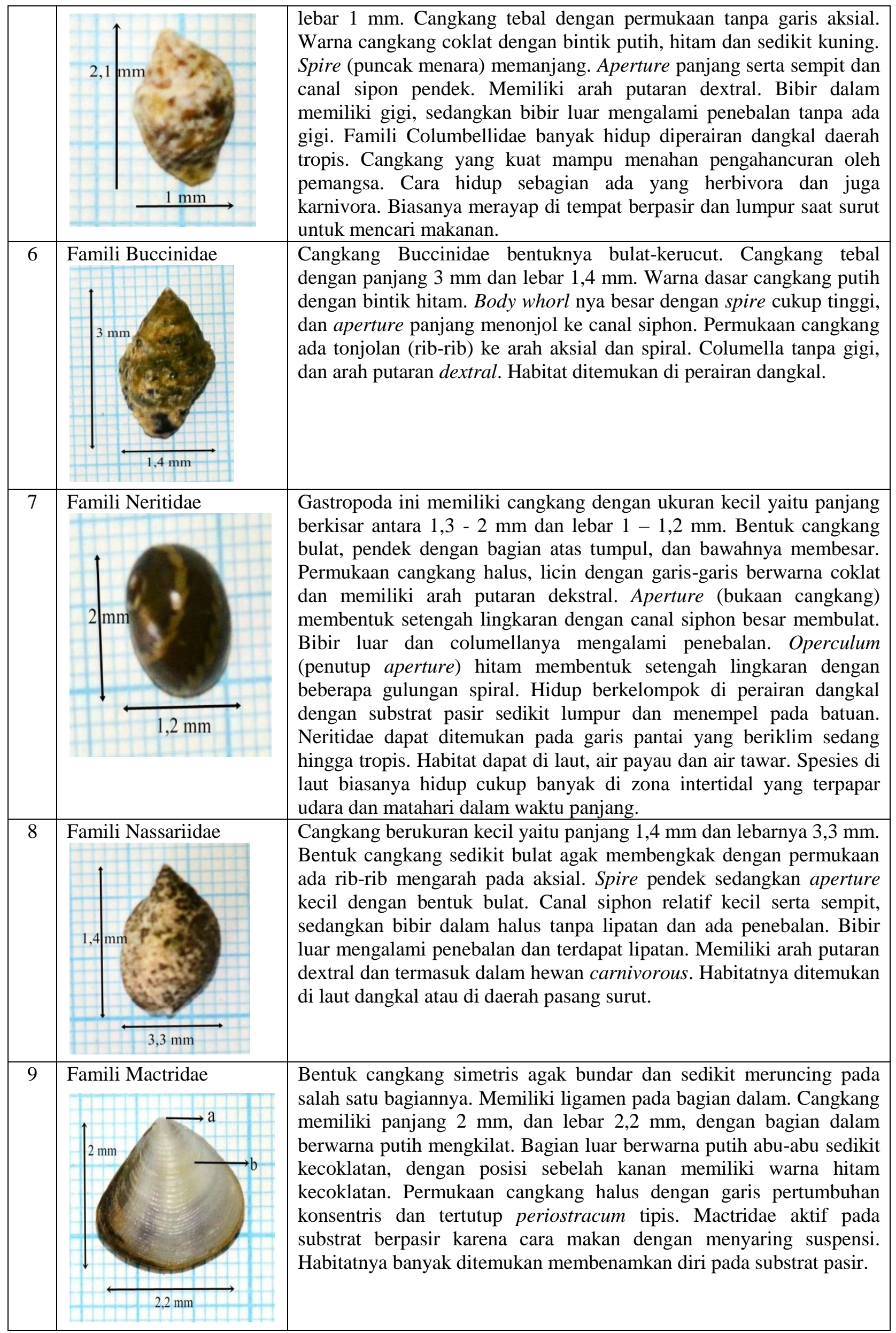




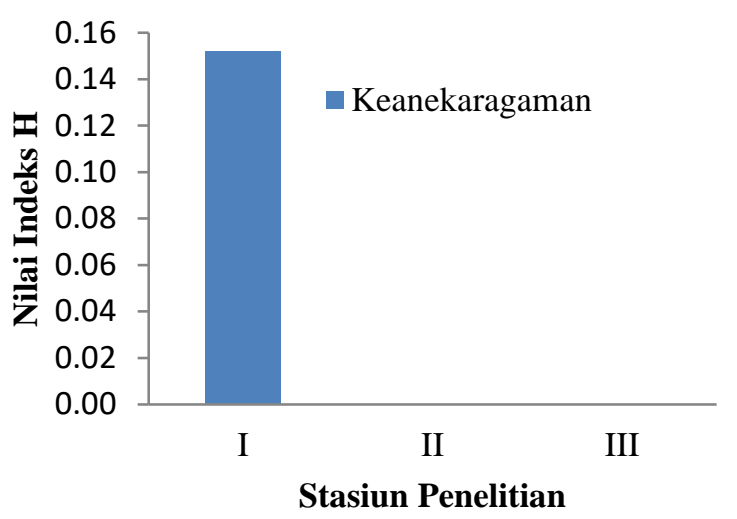

Gambar 3. Indeks keanekaragaman (H') Moluska di setiap stasiun penelitian

Karakteristik stasiun III yaitu pantai berpasir halus dengan arus gelombang lebih tinggi bila dibandingkan stasiun lainnya. Arus gelombang memiliki pengaruh terhadap kehadiran Gastropoda. Daerah dengan aliran gelombang kuat memiliki keanekaragaman rendah dibandingkan yang berarus lemah [11]. Arus yang tinggi menghalangi Gastropoda untuk dapat melekatkan tubuhnya ke substrat. Stasiun III merupakan tempat rekreasi yang banyak terdapat aktivitas wisata. Lokasi ini dijadikan tempat berenang oleh pengunjung dan juga dekat dengan jalur penyebrangan kapal penduduk. Aktivitas pengunjung juga mengganggu kelangsungan hidup Moluska, seperti menginjak-injak substrat dan pengambilan Moluska jenis kerang-kerangan untuk dikoleksi.

Pengukuran Kondisi Lingkungan. Hasil pengukuran parameter lingkungan abiotik di Pantai Pasir Putih didapatkan nilai rata-rata seperti pada Tabel 3.

Tabel 3. Hasil pengukuran kondisi kingkungan

\begin{tabular}{ccccc}
\hline \multirow{2}{*}{ Parameter } & \multicolumn{3}{c}{ Stasiun } & $\begin{array}{c}\text { Baku } \\
\text { Mutu* }\end{array}$ \\
\cline { 2 - 4 } & I & II & III & $26-30$ \\
Suhu $\left({ }^{\circ} \mathrm{C}\right)$ & 27 & 27,7 & 27,8 & $6,5-8,5$ \\
pH & 6 & 6,3 & 6,3 & 6,5 \\
Kedalaman $(\mathrm{cm})$ & 36 & 34,3 & 19,6 & - \\
DO $(\mathrm{mg} / \mathrm{l})$ & 4,2 & 4 & 4,3 & $\geq 4$ \\
BOD $(\mathrm{mg} / \mathrm{l})$ & 3,2 & 2,3 & 3,2 & $\leq 45$ \\
COD $(\mathrm{mg} / \mathrm{l})$ & 1,3 & 1,3 & 1,6 & $\leq 80$ \\
\hline
\end{tabular}

* Keputusan Menteri Lingkungan Hidup No. 51 Tahun 2004

Pengukuran parameter lingkungan dilakukan secara in situ, bersamaan dengan waktu pengambilan sampel Moluska. Pada Tabel 3, terlihat bahwa suhu lingkungan pada masingmasing stasiun rata-rata $27-27,8{ }^{\circ} \mathrm{C}$. Suhu memberikan pengaruh terhadap aktivitas metabolisme, perkembangan organisme, dan bahkan dapat menyebabkan kematian [12]. Peningkatan suhu perairan menyebabkan kelarutan oksigen dalam air menurun, sehingga organisme air kesulitan untuk berespirasi. Setiap organisme memiliki kemampuan toleransi yang berbeda terhadap suhu. Suhu optimum untuk Gastropoda dapat melakukan metabolisme yaitu berkisar $25-32^{\circ} \mathrm{C}$ [12]. Apabila suhu lebih dari $32^{\circ} \mathrm{C}$, maka proses metabolisme Gastropoda terganggu. Suhu optimum untuk Bivalvia berada pada kisaran $25-28^{\circ} \mathrm{C}$ [13]. Apabila suhu di atas optimum, maka tidak cocok untuk perkembangan Bivalvia.

Nilai pH berada pada kisaran 5,7 - 8,4 masih layak untuk kehidupan Moluska [13]. Apabila pH lebih rendah atau lebih tinggi dibawah nilai tersebut, maka dapat mengganggu kehidupan Moluska. Nilai $\mathrm{pH}$ yang rendah menyebabkan kandungan oksigen terlarutnya menurun, sehingga menyebabkan aktivitas respirasi organisme naik, begitu juga sebaliknya jika pH tinggi [14]. Hasil pengukuran diperoleh nilai $\mathrm{pH}$ berkisar antara 6 6,3, sehingga masih dalam kisaran toleransi terhadap biota untuk bertahan hidup.

Pengukuran kedalaman perairan berkisar antara 19,6 - $36 \mathrm{~cm}$. Kedalaman berpengaruh terhadap intensitas cahaya yang masuk ke perairan. Semakin dalam perairan semakin sedikit cahaya yang masuk. Cahaya yang masuk digunakan tumbuhan air untuk melakukan fotosintensis yang berperan menjadi makanan Bivalvia dan Gastropoda herbivora [15]. Hasil pengukuran DO menunjukkan nilai yang hampir seragam yaitu berkisar $4-4,3$ ppm. Kadar DO yang baik untuk biota perairan adalah tidak lebih dari $10 \mathrm{mg} / \mathrm{l}$ [14]. Makrozoobentos membutuhkan kandungan oksigen terlarut berkisar 1,00 - 3,00 $\mathrm{mg} / \mathrm{l}$. Semakin besar oksigen terlarut di perairan, maka akan sangat baik untuk kehidupan makrozoobentos.

Pengukuran BOD pada semua stasiun berkisar 2,3- 3,2 mg/l. Tingginya BOD pada perairan disebabkan adanya banyak aktivitas masyarakat di sekitar, sehingga menambah kandungan organik di perairan tersebut. Perairan dikatakan tercemar, jika nilai BOD melebihi angka $10 \mathrm{mg} / \mathrm{l}$, sedangkan apabila di bawah 3 $\mathrm{mg} / \mathrm{l}$ masih cukup bersih dari mikroorganisme [16]. Hasil pengukuran BOD perairan Pantai Pasir Putih masih berada di kisaran baku mutu, sehingga masih baik untuk kehidupan biota air, serta belum menunjukkan indikasi adanya pencemaran bahan organik di perairan.

Nilai COD pada stasiun rata-rata berkisar antara 1,3 - 1,6 mg/l. Hasil pengukuran COD di stasiun pengamatan masih di bawah batas minimum, sehingga perairan belum tercemar dan masih cukup baik untuk kehidupan Moluska. Meskipun, pengukuran lingkungan menunjukkan bahwa perairan belum tercemar, namun perlu dilakukan penelitian lanjutan mengenai 
kandungan toksik (racun) di perairan, misalnya tentang logam berat. Perairan tersebut diduga mengalami pencemaran bahan logam yang bersumber dari area pemukiman, industri dan jalur perlintasan kapal-kapal pengangkut barang. Hal tersebut perlu diwaspadai karena lebih lanjut dapat menyebabkan terganggunya kestabilan ekosistem dan lingkungan.

Berdasarkan hasil analisis kepadatan dan keanekaragaman Moluska pada setiap stasiun memiliki nilai yang rendah, maka dapat dikatakan bahwa semua stasiun di Pantai Pasir Putih berada dalam kondisi kurang stabil. Rendahnya nilai tersebut mengindikasi bahwa kondisi perairan mengalami tekanan secara ekologi dan lingkungan. Tekanan terjadi disebabkan adanya eksploitasi yang dilakukan oleh masyarakat. Hasil pengamatan terungkap bahwa telah terjadi penangkapan Moluska secara terus-menerus, untuk keperluan koleksi serta komersil yang menyebabkan menurunnya kepadatan dan jumlah Moluska.

Keberadaan Moluska dipengaruhi oleh faktor lingkungan perairan. Hasil pengukuran faktor abiotik $\mathrm{pH}, \mathrm{DO}, \mathrm{BOD}$ dan COD menyatakan bahwa masih berada dalam kisaran toleransi untuk Moluska. Meskipun, pengukuran lingkungan menunjukkan bahwa perairan belum tercemar, namun perlu dilakukan penelitian lanjutan mengenai kandungan toksik (racun) di perairan, misalnya kandungan logam berat di perairan. Perairan diduga mengalami pencemaran bahan logam yang bersumber dari area pemukiman, industri dan jalur perlintasan kapalkapal pengangkut barang.

Dalam mengindikasi ada atau tidaknya pencemaran dapat diketahui dengan menggunakan Moluska. Keduanya memiliki banyak manfaat bagi kehidupan salah satunya dapat digunakan sebagai bioindikator. Hal ini, karena tidak terlepas dari sifat hidupnya yang memiliki mobilitas lambat dan cenderung menetap, serta cara makan yang menyaring suspensi, sehingga menerima setiap perubahan lingkungan yang terjadi.

\section{KESIMPULAN}

Jumlah individu Moluska yang ditemukan di Pantai Pasir Putih Kabupaten Lampung Selatan sebanyak 48 individu yang berasal dari sembilan famili yaitu Cerithiidae, Neritidae, Throchidae, Conidae, Muricidae, Nassaridae, Columbellidae Buccinidae dan Mactridae. Stasiun I memiliki kepadatan Moluska tertinggi yaitu 10,33 Ind/ $\mathrm{m}^{2}$, sedangkan stasiun II memiliki kepadatan $5 \mathrm{Ind} / \mathrm{m}^{2}$ dan stasiun III memiliki kepadatan terendah yaitu $0,67 \mathrm{Ind} / \mathrm{m}^{2}$. Indeks Shannon-Wiener Moluska di
Pantai Pasir Putih termasuk dalam kategori rendah (nilai $\mathrm{H}^{\prime}: 0$ - 0,152). Hasil analisis faktor lingkungan menunjukkan bahwa perairan Pantai Pasir Putih belum tercemar dan masih cukup baik untuk kehidupan Moluska

\section{DAFTAR PUSTAKA}

[1] Wiryawan, et al (1999) Atlas sumberdaya wilayah pesisir Lampung. Bandar Lampung: Pemda Tk I Lampung- CRMP Lampung.

[2] Yuniarti N (2012) Keanekaragaman dan distribusi Bivalvia dan Gastropoda (Moluska) di Pesisir Glayem Juntinyuat, Indramayu, Jawa Barat. Skripsi. Institut Pertanian Bogor.

[3] Romdani AM (2016) Keanekaragaman Gastropoda di kawasan hutan mangrove Desa Baban Kecamatan Gapura Kabupaten Sumenep sebagai sumber belajar Biologi. Skripsi. Universitas Muhammadiyah Malang.

[4] Carpenter KE, Niem VH (1998) The living marine resources of the Western Central Pasific Volume 1. FAO Species identification guide for fishery purpose. FAO: Rome. ISBN 92-5-104051-6. XIV, 686 pp.

[5] Dharma B (1988) Siput dan Kerang Indonesia (Indonesia Shells). Sarana Graha, Jakarta.

[6] Pratiwi MA, Ernawati NM (2016) Analisis kualitas air dan kepadatan moluska pada kawasan ekosistem mangrove, Nusa Lembongan. Journal of Marine and Aquatic Sciences 2(2): 67-72.

[7] Handayani EA (2006) Keanekaragaman jenis Gastropoda di Pantai Randusanga Kabupaten Brebes Jawa Tengah. Skripsi. Universitas Negeri Semarang.

[8] Odum EP (1993) Dasar-dasar Ekologi Edisi Ketiga, Terj. Tjahyono Samingan. Gadjah Mada University Press, Yogyakarta.

[9] Riniatsih I, Kushartono EW (2009) Substrat dasar dan parameter oseanografi sebagai penentu keberadaan Gastropoda dan Bivalvia di Pantai Sluke Kabupaten Rembang. Jurnal Ilmu Kelautan 14(1): 50-59.

[10] Fajri N (2013) Struktur komunitas makrozoobentos di Perairan Pantai Kuwang Wae Kabupaten Lombok Timur. Jurnal Educatio 8(2): 81-100.

[11] Ernanto R, Agustriani F, Aryawati R (2010) Struktur Komunitas Gastropoda pada ekosistem mangrove di Muara Sungai Batang Ogan Komering Ilir Sumatera Selatan. Jurnal Maspari 01: 73-78.

[12] Amalina AD (2014) Struktur dan komposisi Komunitas Gastropoda dan Bivalvia di 
Tambak Polikultur Desa Kupang, Kecamatan Jabon, Kabupaten Sidoarjo-Jawa Timur. Skripsi. Universitas Negeri Malang.

[13] Izzah NA, Roziaty E (2016) Keanekaragaman makrozoobentos di pesisir pantai Desa Panggung Kecamatan Kedung Kabupaten Jepara. Jurnal Bioeksperimen 2(2): 140-148.

[14] Maharani HW (2007) Kajian kualitas perairan di Pantai Kota Bandar Lampung berdasarkan komunitas hewan makrobenthos. Tesis. Universitas Diponegoro.

[15] Ulmaula Z, Purnawan S, Sarong MA (2016) Keanekaragaman Gastropoda dan Bivalvia berdasarkan karateristik sedimen daerah intertidal kawasan Pantai Ujong Pancu Kecamatan Peukan Bada Kabupaten Aceh Besar. Jurnal Ilmiah Mahasiswa Kelautan dan Perikanan Unsyiah 1(1): 124-134.

[16] Gundo MT (2010) Kerapatan, keanekaragaman, dan pola penyebaran Gastropoda air tawar di Perairan Danau Poso. Media Litbang Sulteng III (2): 137-143. 